\title{
Mediterranean Journal of Hematology and Infectious Diseases
}

\section{$\underline{\text { Original Article }}$}

\section{Treatment Outcomes and Clinical Relevance in Patients with Double Expressor DLBCL}

Sirapat Rungwittayatiwat ${ }^{1}$, Paisarn Boonsakan ${ }^{2}$, Pichika Chantrathammachart ${ }^{1}$, Teeraya Puavilai ${ }^{1}$, Sulada Pukiat $^{1}$, Sithakom Phusanti ${ }^{1,3}$, Kochawan Boonyawat ${ }^{1}$, Pathawut Wacharapornin ${ }^{1}$, Pantep Angchaisuksiri ${ }^{1}$, Artit Ungkanont ${ }^{1,3}$, Suporn Chuncharunee ${ }^{1}$ and Pimjai Niparuck ${ }^{1}$.

${ }^{1}$ Division of Hematology, Department of Medicine, Ramathibodi Hospital, Mahidol University, Bangkok, Thailand.

${ }^{2}$ Department of Pathology, Ramathibodi Hospital, Mahidol University, Bangkok, Thailand.

${ }^{3}$ Department of Medicine, Chakri Naruebodindra Medical Institute, Mahidol University, Bangkok, Thailand.

Competing interests: The authors declare no conflict of Interest.

Abstract. Background: Double-expressor lymphoma (DEL) was found to account for 20- 30\% of DLBCL. We conducted this study to analyze the survival, the clinical presentation, and the factors associated with treatment outcomes in DEL-DLBCL.

Methods: A retrospective study of 291 patients diagnosed with DLBCL during January 2015 December 2018 was conducted.

Results: Of the 291 patients, the median age was 63 years, germinal center B cell-like DLBCL (GCB) and non-GCB subtypes were found in $32 \%$ and $68 \%$, respectively. DEL was found in $46 \%$ of 264 patients with available immunohistochemistry staining for MYC protein. Patients with DEL was significantly more common in elderly patients $(p=0.017)$ and non-GCB subtype $(p=0.006)$. High serum lactate dehydrogenase (LDH) levels and high Ki-67 index were significantly found in DEL patients than non-DEL patients $(p=0.024$ and $p=0.04$, respectively). The $3 y-O S$ rate was shorter in the DEL group than in the non-DEL group, $58.7 \%$ versus $78.9 \%(p=0.026)$, whereas no significant difference in $3 y$-DFS was identified between these groups $(58.4 \%$ versus $67.7 \%, p=$ 0.343). Independent factors affecting OS and DFS in DEL patients were ECOG 3-4, high LDH levels, extranodal involvement $>1$ site, high IPI, and stage III-IV in univariate analysis. Conclusions: High incidence of DEL was observed in this study, especially in patients aged 60 years or older and non-GCB subtype. Patients with DEL showed dismal DFS and OS.

Keywords: Diffuse large B cell lymphoma; Double expressor lymphoma; GCB, Non GCB; Survival.

Citation: Rungwittayatiwat S., Boonsakan P., Chantrathammachart P., Puavilai T., Pukiat S., Phusanti S., Boonyawat K., Wacharapornin P., Angchaisuksiri P., Ungkanont A., Chuncharunee S., Niparuck P. Treatment outcomes and clinical relevance in patients with double expressor DLBCL. Mediterr J Hematol Infect Dis 2021, 13(1): e2021063, DOI: http://dx.doi.org/10.4084/MJHID.2021.063

This is an Open Access article distributed under the terms of the Creative Commons Attribution License (https://creativecommons.org/licenses/by-nc/4.0), which permits unrestricted use, distribution, and reproduction in any medium, provided the original work is properly cited.

Correspondence to: Pimjai Niparuck, Division of Hematology, Department of Medicine, Ramathibodi Hospital, Mahidol University, Thailand. Tel: +662-201-1392 Fax: +662-201-1392. E-mail: niparuckblue@gmail.com

Introduction. Diffuse large B-cell lymphoma (DLBCL) is the most common aggressive B-cell non-Hodgkin lymphoma (NHL), accounting for $65 \%$ of NHL in Thailand. ${ }^{1}$ It is a heterogeneous disease classified as germinal center-like B-cell (GCB) and non-germinal B-cell subtypes that arise from different cells of origin (COO). Hans algorithm including CD10, BCL6, and MUM1 
protein expressions are used for the classification of COO of DLBCL, and the common methods for determining the $\mathrm{COO}$ are immunohistochemistry (IHC) and gene expression profiling (GEP). ${ }^{2} \mathrm{MYC}$ and BCL2 protein expressions are found in 30-50\% and $20-35 \%$ DLBCL, respectively. ${ }^{3}$ Translocations of MYC and BCL2 and/or BCL6 are called triple and double-hit lymphomas (TH/DHL), whereas the coexpression of MYC and BCL2 proteins without MYC/BCL2 and/or BCL6 rearrangement is described as double-expressor lymphoma (DEL). ${ }^{4}$ The progression-free survival (PFS) and overall survival (OS) were dismal in DEL patients receiving R-CHOP therapy. Rituximab plus CHOP (cyclophosphamide, doxorubicin, vincristine, and prednisone) exhibited a favorable outcome for DLBCL-GCB (2y-PFS of $64 \%$ and $2 y-O S$ of $74 \%$ ), compared with those in non-GCB subtypes (2y-PFS of $28 \%$ and $2 y-O S$ of $46 \%){ }^{5}$ The OS in patients with DEL and non-DEL were 20 and 36 months, respectively; DEL patients receiving R-CHOP had a higher relapse rate than treatment with R-EPOCH $(80 \%$ versus $18 \%) .{ }^{5}$ The previous study of Italian patients with DEL illustrated that R-DA-EPOCH every three weeks had $2 \mathrm{y}$-OS longer than that in DEL patients treated with R-CHOP, $90 \%$, and $67 \%$, respectively, whereas 2y-PFS in DEL patients receiving R-DA-EPOCH and R-CHOP were 57\% and $51 \%$, respectively. ${ }^{6}$ Although the previous studies have demonstrated worse outcomes in patients with DEL, the survival and the prognostic factors affecting outcome in this subtype of DLBCL in the Asian population are not well known. Hence, we conducted this study to analyze the survival, clinical presentation, and factors associated with treatment outcomes in DEL.

\section{Materials and Methods.}

Patients. Patients with newly diagnosed DLBCL receiving chemotherapy plus rituximab or chemotherapy alone at Ramathibodi Hospital between January 2015 and December 2018 were recruited and reviewed. All patients were 18 years of age and older. The diagnosis and subtypes of DLBCL were reviewed and classified according to the 2016 revision of WHO classification by an experienced hemato-pathologist. ${ }^{4,7,8}$ DLBCL with the cut-off level of $40 \%$ for MYC positivity and $50 \%$ for BCL2 protein coexpression was classified as double expressor (DE)-DLBCL, whereas this subtype with MYC and BCL2 and/or BCL6 rearrangement was classified as THL/DHL. ${ }^{7}$ In this study, fluorescence in situ hybridization (FISH) testing for MYC, BCL2, and BCL6 rearrangement was performed in DLBCL patients with MYC protein expression $>40 \%$.

Demographic characteristics of patients including age, serum lactate dehydrogenase (LDH), ECOG, site of lesion (extranodal/nodal), number of extranodal involvement, bulky lesion, International prognostic index (IPI) score, chemotherapy regimen, treatment with and without surgery or radiation therapy were recorded. We excluded primary CNS lymphoma, primary mediastinal B cell lymphoma, and indolent lymphoma with large cell transformation. Patients receiving prior chemotherapy and/or radiation therapy were also excluded. Six to eight cycles of intrathecal methotrexate administration at a dose of $15 \mathrm{mg}$ were performed for all DLBCL patients with a high (4-6 points) CNS-IPI score ${ }^{9}$ and/or testicular, adrenal/kidney or breast involvement.

Statistical analysis. The primary endpoints were to analyze the rates of overall survival (OS) and diseasefree survival (DFS) in patients with double expressor lymphoma (DEL), and secondary endpoints were to evaluate the response and the complete remission (CR) rates between DEL and non-DEL and identify factors affecting survival in DEL and non-DEL patients. The response rate (RR) was defined as the percentage of patients who achieved at least partial remission (reduction in tumor size $>50 \%$ after treatment) and CR (no evidence of tumor after treatment).

Kaplan-Meier analysis and log-rank test were used to evaluate and compare DFS and OS between patients with DEL and non-DEL. The Cox regression model was applied for multivariate survival analysis and identify independent prognostic factors for survival. A Chisquare test was used to compare the clinical factors and treatment outcomes between DEL and non-DEL groups. Finally, all statistical analysis was performed using SPSS version 18 , and a $P$ value less than 0.05 was considered statistically significant.

This retrospective study was approved by the Local Ethics Committee on Human Rights related to research involving human subjects at Ramathibodi Hospital, Mahidol University.

\section{Results.}

Patient characteristics. The study included 291 DLBCL patients with a median age of 63 years (19-92 years), 157 of whom were female, and 184 patients were older than 60 years. The tissue diagnosis was taken from lymph nodes $(51 \%)$, bone marrow $(0.3 \%)$, and other organs (51\%). Extranodal involvement was found in 169 patients $(58 \%)$, which the common sites of extranodal involvement were the gastrointestine $(22 \%)$, bone marrow (17\%), and nasal cavity (11\%). GCB and nonGCB subtypes were found in $92(32 \%)$ and 199 patients (68\%), respectively. In the GCB group, 75 patients had CD10+, and 17 patients were BCL6+/MUM1-. DEL was seen in 121 out of 264 patients with available IHC 
Table 1. Characteristics of patients diagnosed with DEL versus non-DEL subtypes.

\begin{tabular}{|c|c|c|c|c|c|}
\hline \multirow[t]{2}{*}{ Parameters } & \multirow{2}{*}{$\begin{array}{c}\text { DLBCL } \\
\text { (all subtypes) } \\
\text { N=291 (\%) }\end{array}$} & \multicolumn{3}{|c|}{ DEL versus non DEL } & \multirow{2}{*}{$\begin{array}{c}\text { DLBCL, unknown } \\
\text { subtype } \\
\text { (insufficient tissue) } \\
\mathbf{N}=27(\%)\end{array}$} \\
\hline & & $\begin{array}{c}\text { DEL; } \\
\mathrm{N}=121(\%)\end{array}$ & $\begin{array}{c}\text { non-DEL; } \\
\mathrm{N}=143(\%)\end{array}$ & $p$ & \\
\hline $\begin{array}{l}\text { Sex } \\
\text { - Male } \\
\text { - Female }\end{array}$ & $\begin{array}{l}134(46) \\
157(54)\end{array}$ & $\begin{array}{l}50(41.3) \\
71(58.7)\end{array}$ & $\begin{array}{l}69(48.3) \\
74(51.7)\end{array}$ & 0.305 & $\begin{array}{l}15(55) \\
12(44)\end{array}$ \\
\hline $\begin{array}{l}\text { Age (years) } \\
-<60 \\
-\geq 60\end{array}$ & $\begin{array}{l}107(36.8) \\
184(63.2)\end{array}$ & $\begin{array}{l}36(29.7) \\
85(70.2)\end{array}$ & $\begin{array}{l}62(43.4) \\
81(56.6)\end{array}$ & 0.017 & $\begin{array}{c}9(33) \\
18(66)\end{array}$ \\
\hline $\begin{array}{l}\overline{E C O G} \\
-0-2 \\
-3-4 \\
\end{array}$ & $\begin{array}{c}256(68) \\
35(12) \\
\end{array}$ & $\begin{array}{c}105(86.8) \\
16(13.2) \\
\end{array}$ & $\begin{array}{c}125(87.4) \\
18(12.6) \\
\end{array}$ & 0.795 & $\begin{array}{c}26(96) \\
1(4) \\
\end{array}$ \\
\hline $\begin{array}{l}\text { LDH level } \\
\text { - Normal } \\
\text { - High }\end{array}$ & $\begin{array}{l}101(34.7) \\
190(65.3)\end{array}$ & $\begin{array}{l}34(28.1) \\
87(71.9)\end{array}$ & $\begin{array}{l}61(42.6) \\
82(57.4)\end{array}$ & 0.024 & $\begin{array}{c}6(22) \\
21(78)\end{array}$ \\
\hline $\begin{array}{l}\text { Stage } \\
\text { - I- II } \\
\text { - III- IV } \\
\end{array}$ & $\begin{array}{l}119(40.9) \\
172(69.1) \\
\end{array}$ & $\begin{array}{l}50(41.3) \\
71(58.7) \\
\end{array}$ & $\begin{array}{l}59(41.3) \\
84(58.7) \\
\end{array}$ & 0.859 & $\begin{array}{l}10(37) \\
17(63) \\
\end{array}$ \\
\hline $\begin{array}{l}\text { Extranodal involvement } \\
\text { - No } \\
\text { - Yes } \\
\end{array}$ & $\begin{array}{l}122(41.9) \\
169(58.1) \\
\end{array}$ & $\begin{array}{l}53(43.8) \\
68(56.2) \\
\end{array}$ & $\begin{array}{l}59(41.3) \\
84(58.7) \\
\end{array}$ & 0.81 & $\begin{array}{l}10(37) \\
17(63) \\
\end{array}$ \\
\hline $\begin{array}{l}\text { Number of extranodal site } \\
\text { involvement } \\
-0-1 \\
->1\end{array}$ & $\begin{array}{c}244(83.8) \\
47(16.2) \\
\end{array}$ & $\begin{array}{c}100(82.6) \\
21(17.4) \\
\end{array}$ & $\begin{array}{l}123(86) \\
20(12)\end{array}$ & 0.383 & $\begin{array}{l}21(78) \\
6(22)\end{array}$ \\
\hline $\begin{array}{l}\text { Bulky lesion } \geq 5 \mathrm{~cm} \\
\text { - No } \\
\text { - Yes } \\
\end{array}$ & $\begin{array}{l}188(64.6) \\
103(35.4) \\
\end{array}$ & $\begin{array}{l}74(61.2) \\
47(38.8) \\
\end{array}$ & $\begin{array}{l}95(66.5) \\
48(33.5) \\
\end{array}$ & 0.413 & $\begin{array}{l}19(70) \\
8(30) \\
\end{array}$ \\
\hline $\begin{array}{l}\text { Bulky lesion } \geq 7.5 \mathrm{~cm} \\
\text { - No } \\
\text { - Yes }\end{array}$ & $\begin{array}{l}152(52.2) \\
139(47.8) \\
\end{array}$ & $\begin{array}{l}58(47.9) \\
63(52.1) \\
\end{array}$ & $\begin{array}{l}76(53) \\
67(47)\end{array}$ & 0.397 & $\begin{array}{c}18(67) \\
9(33) \\
\end{array}$ \\
\hline $\begin{array}{l}\text { COO } \\
\text { - GCB } \\
\text { - Non-GCB } \\
\end{array}$ & $\begin{array}{c}92(31.6) \\
199(68.4) \\
\end{array}$ & $\begin{array}{l}28(23.1) \\
93(76.9)\end{array}$ & $\begin{array}{l}57(40) \\
86(60) \\
\end{array}$ & 0.006 & $\begin{array}{c}7(26) \\
20(74) \\
\end{array}$ \\
\hline $\begin{array}{l}\text { Subtype } \\
\text { - DHL } \\
\text { - Non-DHL } \\
\text { - Uninterpretable } \\
\end{array}$ & $\begin{array}{c}\mathrm{N}=120 \\
4(3.4) \\
100(83.3) \\
16(13.3) \\
\end{array}$ & $\begin{array}{l}\mathrm{N}=106 \\
3(2.8) \\
89(84) \\
14(13.2)\end{array}$ & $\begin{array}{c}\mathrm{N}=14 \\
1(7.1) \\
11(78.6) \\
2(14.3) \\
\end{array}$ & 0.208 & $\begin{array}{l}0 \\
0 \\
0\end{array}$ \\
\hline $\begin{array}{l}\text { IPI } \\
\text { - Low } \\
\text { - Low- intermediate } \\
\text { - High- intermediate } \\
\text { - High }\end{array}$ & $\begin{array}{l}91(31.3) \\
92(31.6) \\
68(23.4) \\
40(13.7) \\
\end{array}$ & $\begin{array}{l}31(25.6) \\
43(35.5) \\
25(20.7) \\
22(18.2)\end{array}$ & $\begin{array}{c}53(37) \\
43(30) \\
31(21.7) \\
16(11.3) \\
\end{array}$ & 0.113 & $\begin{array}{c}7(26) \\
6(22) \\
12(44) \\
2(8) \\
\end{array}$ \\
\hline $\begin{array}{l}\text { BCL6 expression } \\
- \text { No } \\
- \text { Yes } \\
\end{array}$ & $\begin{array}{c}64(22) \\
227(78) \\
\end{array}$ & $\begin{array}{l}22(18.2) \\
99(81.8) \\
\end{array}$ & $\begin{array}{c}37(26) \\
106(74) \\
\end{array}$ & 0.127 & $\begin{array}{r}5(19) \\
22(81) \\
\end{array}$ \\
\hline $\begin{array}{l}\text { MUM1 expression } \\
\text { - No } \\
\text { - Yes } \\
\end{array}$ & $\begin{array}{r}71(24.4) \\
220(75.6) \\
\end{array}$ & $\begin{array}{c}19(15.7) \\
102(84.3)\end{array}$ & $\begin{array}{l}49(34) \\
94(66) \\
\end{array}$ & 0.001 & $\begin{array}{c}3(11) \\
24(89) \\
\end{array}$ \\
\hline $\begin{array}{l}\text { Rituximab based regimen } \\
\text { - No } \\
\text { - Yes }\end{array}$ & $\begin{array}{c}87(29.9) \\
204(70.1) \\
\end{array}$ & $\begin{array}{l}34(28.1) \\
87(71.9) \\
\end{array}$ & $\begin{array}{l}46(32.2) \\
97(67.8) \\
\end{array}$ & 0.589 & $\begin{array}{c}7(26) \\
20(74) \\
\end{array}$ \\
\hline $\begin{array}{l}\text { Chemotherapy regimens } \\
\text { - CHOP } \\
\text { - R-CHOP } \\
\text { - DA-EPOCH } \\
\text { - R-DAEPOCH } \\
\text { - Other regimens } \\
\text { - R- other regimens } \\
\end{array}$ & $\begin{array}{c}59(20.3) \\
184(63.2) \\
2(0.7) \\
15(5.2) \\
26(8.9) \\
5(1.7) \\
\end{array}$ & $\begin{array}{c}21(17.4) \\
74(61.2) \\
1(0.8) \\
12(10) \\
11(9) \\
2(1.6) \\
\end{array}$ & $\begin{array}{c}32(22.5) \\
90(63) \\
1(0.7) \\
3(2) \\
14(9.7) \\
3(2.1) \\
\end{array}$ & - & $\begin{array}{c}6(22) \\
20(74) \\
0 \\
0 \\
1(3.7) \\
0 \\
\end{array}$ \\
\hline $\begin{array}{l}\text { RT } \\
\text { - No } \\
\text { - Frontline } \\
\end{array}$ & $\begin{array}{l}199(68.4) \\
92(31.6)\end{array}$ & $\begin{array}{l}83(68.6) \\
38(31.4) \\
\end{array}$ & $\begin{array}{l}97(67.8) \\
46(32.2) \\
\end{array}$ & 0.809 & $\begin{array}{l}19(70) \\
8(30)\end{array}$ \\
\hline
\end{tabular}




\begin{tabular}{|c|c|c|c|c|c|}
\hline $\begin{array}{l}\text { Tumor resection } \\
\text { - No } \\
\text { - Frontline } \\
\text { - Relapse/ refractory }\end{array}$ & $\begin{array}{c}259(89) \\
29(10) \\
3(1)\end{array}$ & $\begin{array}{c}111(91.7) \\
7(5.8) \\
3(2.5)\end{array}$ & $\begin{array}{c}122(85.3) \\
21(14.7) \\
0(0)\end{array}$ & 0.015 & $\begin{array}{c}26(96) \\
1(4) \\
0\end{array}$ \\
\hline $\begin{array}{l}\mathrm{Ki}-67(\%) \\
-<50 \\
-50-80 \\
->80\end{array}$ & $\begin{array}{c}8(2.7) \\
130(44.7) \\
153(52.6)\end{array}$ & $\begin{array}{c}1(0.8) \\
46(38) \\
74(61.2)\end{array}$ & $\begin{array}{c}5(3.5) \\
73(51) \\
65(45.5)\end{array}$ & 0.04 & $\begin{array}{c}2(7) \\
11(41) \\
14(52)\end{array}$ \\
\hline
\end{tabular}

Abbreviation: ECOG: Eastern Co-Operative Oncology Group, LDH: lactate dehydrogenase, COO: cell of origin, GCB: germinal B-cell subtype, DHL: double hit lymphoma, IPI: international prognostic index, RT: radiation therapy.

staining for MYC protein (45.8\%), and it was detected in non-GCB subtype $(77 \%)$ greater than GCB-DLBCL (23\%). BCL6+ and MUM1+ were found in $82.6 \%$ and $84.3 \%$ of DEL patients, respectively.

Of 121 DEL patients, the median age was 67 years (28- 90 years). Patients aged $>60$ years, stage III-IV, extranodal involvement and ECOG performance 3-4 were observed in $70 \%, 59 \%, 56.2 \%$, and $13 \%$ of DEL patients, respectively, whereas high LDH levels, high IPI, and bulky lesion (maximum tumor diameter $>7.5 \mathrm{~cm}$ ) were found in $72 \%, 18 \%$ and $52 \%$ of DEL patients, respectively. In the group of DE-DLBCL patients, extranodal involvement was found in 68 patients $(56 \%)$, the common sites of lymphoma involvements were BM $(14 \%)$, nasal cavity $(12 \%)$, stomach, small and large bowel $(12 \%)$, lung and pleura $(10 \%)$. Central nervous system involvement was found in only $3 \%$ of DEL patients. FISH for MYC, BCL2, and BCL6 gene rearrangement was done in $87.6 \%$ of 121 DEL patients (only available tissue samples), and DHL was detected in three patients, including two patients with GCB and one patient with non-GCB. BCL6+ and MUM1+ were found in $82.6 \%$ and $84.3 \%$ of DEL patients, respectively. In the non-DEL group (143 patients), MYC+/BCL2DLBCL was detected by IHC in 17 patients which FISH for MYC/BCL2/ BCL6 gene rearrangement was performed in $82 \%$ of 17 patients.

Patients aged $>60$ years, high LDH levels, Ki-67 $>80 \%$, non-GCB subtype, and MUM1+ DLBCL were found significantly in DEL patients compared to those in non-DEL DLBCL. Patients' characteristics are shown in Table 1.

Treatment outcomes. During the entire study period, Thai patients with DLBCL treated under the civil servant medical benefit scheme and health insurance could access treatment with rituximab-based chemotherapy. In contrast, patients with DLBCL who were treated under the universal coverage and social security schemes could not claim rituximab therapy reimbursement. Therefore, only 204 patients $(70 \%)$ received rituximab based chemotherapy, $184(63 \%), 59(20 \%), 15(5 \%), 2(1 \%)$ and 31 patients $(11 \%)$ were treated with R-CHOP, CHOP, R-DA-EPOCH, DA-EPOCH, and other chemotherapy regimens, respectively. In addition, DAEPOCH was given depending on the personalized chemotherapy selection for patients with DLBCL who were younger than 60 years and suitable for DA-EPOCH therapy; however, the current frontline standard of treatment DLBCL (non-THL/DHL) remains CHOP regimen.

The CR rate and survival analysis were performed only in patients with DEL (87 patients) and non-DEL DLBCL (97 patients) treated with rituximab-based chemotherapy. CR rates were seen in $87 \%$ and $93 \%$ of DEL and non-DEL patients, respectively. In addition, $91 \%$ of non-GCB patients with DEL and $76 \%$ of GCB patients with DEL achieved CR. ECOG 0-2, normal LDH levels, stage I-II, extranodal involvement $<1$ site, and low or intermediate IPI were significantly associated with higher CR rates in both DEL and non-DEL subtypes (Table 2).

In the entire study population, 1y-OS, 3y-OS, 1y-DFS and $3 y$-DFS were $79.5 \%, 62.9 \% 68.5 \%$ and $58.4 \%$, respectively. The survival analysis was restricted to DEL and non-DEL patients who received rituximab-based chemotherapy (R-chemo). After a median follow-up of 26.5 months, 1y-OS, 3y-OS, 1y-DFS and 3y-DFS rates in DEL patients were $86.7 \%, 58.7 \%, 69.7 \%, 58.4 \%$, respectively. The 3y-OS rate was significantly shorter in the DEL group than in the non-DEL group who were treated with R-chemo $(58.7 \%$ vs. $78.9 \%, \mathrm{p}=0.026)$, whereas there was no significant difference in $3 y-D F S$ was identified between these groups $(58.4 \%$ vs. $67.7 \%$, $\mathrm{p}=0.343$ ). The survival curves are shown in Figure 1. After a median follow-up duration of 25 months, the 1yOS rates in patients with DEL and non-DEL who received R-CHOP were $86.7 \%$ and $94.3 \%$, respectively, whereas the $3 y-O S$ rates in these groups were $58.7 \%$ and $82.6 \%$, respectively $(\mathrm{p}=0.004)$. In addition, the $1 \mathrm{y}-\mathrm{DFS}$ rates in the DEL and non-DEL patients treated with RCHOP were $68.4 \%$ and $84.9 \%$, respectively, whereas the $3 y$-DFS rates in these groups were $50.2 \%$ and $70.5 \%$, respectively $(p=0.19)$. Figure 2 Patients with refractory or relapsed $(\mathrm{R} / \mathrm{R}) \mathrm{DEL}$ and non-DEL after R-chemo therapy were treated with salvage chemotherapy regimens such as ifosfamide, carboplatin, and etoposide (ICE); cisplatin, cytarabine, and dexamethasone (DHAP); etoposide, methylprednisolone, cytarabine, and platinum (ESHAP); ifosfamide, methotrexate, and etoposide (IMVP-16); rituximab and bendamustine (RB); or PD-1 inhibitors. Among 33 patients with DEL, 
Table 2. Factors affecting response of rituximab based regimens in patients with DEL and non-DEL subtypes.

\begin{tabular}{|c|c|c|c|c|}
\hline \multirow[t]{2}{*}{ Factors } & \multicolumn{2}{|c|}{ DEL $(\mathbf{N}=87)$} & \multicolumn{2}{|c|}{ non-DEL $(N=97)$} \\
\hline & CR (\%) & $P$ & CR (\%) & $P$ \\
\hline $\begin{array}{l}\text { Age (years) } \\
-<60 \\
-\geq 60\end{array}$ & $\begin{array}{l}19 / 24(79) \\
57 / 63(90)\end{array}$ & 0.303 & $\begin{array}{l}41 / 45(91) \\
49 / 52(94)\end{array}$ & 0.554 \\
\hline $\begin{array}{l}\text { ECOG } \\
-0-2 \\
-3-4 \\
\end{array}$ & $\begin{array}{c}73 / 82(89) \\
3 / 5(60)\end{array}$ & 0.048 & $\begin{array}{c}83 / 88(94) \\
7 / 9(78) \\
\end{array}$ & 0.068 \\
\hline $\begin{array}{l}\text { LDH level } \\
\text { - Normal } \\
\text { - High } \\
\end{array}$ & $\begin{array}{l}30 / 31(97) \\
46 / 56(80) \\
\end{array}$ & 0.019 & $\begin{array}{l}41 / 43(95) \\
49 / 54(91) \\
\end{array}$ & 0.384 \\
\hline $\begin{array}{l}\text { Stage } \\
\text { - I- II } \\
\text { - III- IV } \\
\end{array}$ & $\begin{array}{l}37 / 39(95) \\
39 / 48(81)\end{array}$ & 0.019 & $\begin{array}{l}42 / 43(98) \\
48 / 54(89)\end{array}$ & 0.097 \\
\hline $\begin{array}{l}\text { Extranodal involvement } \\
\text { - No } \\
\text { - Yes }\end{array}$ & $\begin{array}{l}29 / 33(88) \\
47 / 54(87) \\
\end{array}$ & 0.608 & $\begin{array}{l}30 / 31(97) \\
60 / 66(91)\end{array}$ & 0.298 \\
\hline $\begin{array}{l}\text { Number of extranodal site involvement } \\
-0-1 \\
->1\end{array}$ & $\begin{array}{c}67 / 73(92) \\
9 / 14(64)\end{array}$ & 0.024 & $\begin{array}{l}79 / 84(94) \\
11 / 13(85)\end{array}$ & 0.221 \\
\hline $\begin{array}{l}\text { Bulky lesion }(\mathrm{MTD} \geq 5 \mathrm{~cm}) \\
\text { - Negative } \\
\text { - Positive }\end{array}$ & $\begin{array}{l}37 / 41(90) \\
39 / 46(85)\end{array}$ & 0.251 & $\begin{array}{l}52 / 54(96) \\
38 / 43(88)\end{array}$ & 0.134 \\
\hline $\begin{array}{l}\text { Bulky lesion }(\mathrm{MTD} \geq 7.5 \mathrm{~cm}) \\
\text { - Negative } \\
\text { - Positive }\end{array}$ & $\begin{array}{l}47 / 51(92) \\
29 / 36(81) \\
\end{array}$ & 0.163 & $\begin{array}{l}63 / 68(93) \\
27 / 29(93) \\
\end{array}$ & 0.937 \\
\hline $\begin{array}{l}\text { COO } \\
- \text { GCB } \\
\text { - Non-GCB } \\
\end{array}$ & $\begin{array}{l}16 / 21(76) \\
60 / 66(91) \\
\end{array}$ & 0.103 & $\begin{array}{l}51 / 55(93) \\
39 / 42(93)\end{array}$ & 0.98 \\
\hline $\begin{array}{l}\text { IPI-risk } \\
\text { - Low } \\
\text { - Low- intermediate } \\
\text { - High- intermediate } \\
\text { - High }\end{array}$ & $\begin{array}{c}24 / 24(100) \\
32 / 37(86) \\
12 / 14(86) \\
8 / 12(67) \\
\end{array}$ & 0.034 & $\begin{array}{c}36 / 37(97) \\
31 / 34(91) \\
18 / 19(95) \\
5 / 7(71) \\
\end{array}$ & 0.105 \\
\hline $\begin{array}{l}\text { KI-67 (\%) } \\
-<50 \\
-50-80 \\
->80\end{array}$ & $\begin{array}{l}1 / 1(100) \\
12 / 14(86) \\
63 / 72(88)\end{array}$ & 0.901 & $\begin{array}{l}4 / 4(100) \\
23 / 24(96) \\
63 / 69(91)\end{array}$ & 0.647 \\
\hline $\begin{array}{l}\text { Chemotherapy regimen } \\
\text { - R-CHOP } \\
\text {-R-DA-EPOCH }\end{array}$ & $\begin{array}{l}64 / 75(85) \\
10 / 12(83) \\
\end{array}$ & 0.989 & $\begin{array}{c}85 / 94(90) \\
3 / 3(100) \\
\end{array}$ & 0.888 \\
\hline $\begin{array}{l}\text { RT } \\
\text {-No } \\
\text {-Frontline } \\
\end{array}$ & $\begin{array}{l}48 / 55(87) \\
28 / 32(88) \\
\end{array}$ & 0.727 & $\begin{array}{l}61 / 67(91) \\
29 / 30(97)\end{array}$ & 0.323 \\
\hline $\begin{array}{l}\text { RT }(\mathrm{MTD} \geq 5 \mathrm{~cm}) \\
\text {-No } \\
\text {-Frontline }\end{array}$ & $\begin{array}{l}20 / 24(83) \\
19 / 23(83)\end{array}$ & 0.880 & $\begin{array}{l}24 / 28(86) \\
14 / 15(93)\end{array}$ & 0.458 \\
\hline $\begin{array}{l}\text { RT }(\mathrm{MTD} \geq 7.5 \mathrm{~cm}) \\
\text {-No } \\
\text {-Frontline }\end{array}$ & $\begin{array}{l}13 / 16(81) \\
16 / 19(84)\end{array}$ & 0.935 & $\begin{array}{l}15 / 16(94) \\
12 / 13(92)\end{array}$ & 0.879 \\
\hline
\end{tabular}

$52 \%$ received more than one salvage chemotherapy regimen, versus $56 \%$ of patients in the non-DEL group (27 patients). In total, $12 \%$ and $11 \%$ of patients with $\mathrm{R} / \mathrm{R}$ DEL and non-DEL, respectively, had CNS involvement. CR was achieved after salvage chemotherapy for $6 \%$ and $22 \%$ of patients in the R/R DEL and non-DEL groups, respectively. In the group of patients with $\mathrm{R} / \mathrm{R} \mathrm{DE}-$ DLBCL, 94\% did not respond to salvage chemotherapy and died from progressive disease (PD), whereas $22 \%$ of
non-DEL patients with $\mathrm{R} / \mathrm{R}$ disease achieved $\mathrm{CR}$ after salvage therapy and were still alive at the end of the study.

In univariate analysis, parameters significantly associated with poorer OS in both DEL and non-DEL patients were ECOG 3-4 and high IPI. In contrast, high LDH level, stage III-IV, extranodal involvement> 1 site, GCB subtype, and high-intermediate or high IPI were independent factors affecting OS only in DEL patients (Table 3). Only high LDH levels and stage III-IV were 
A

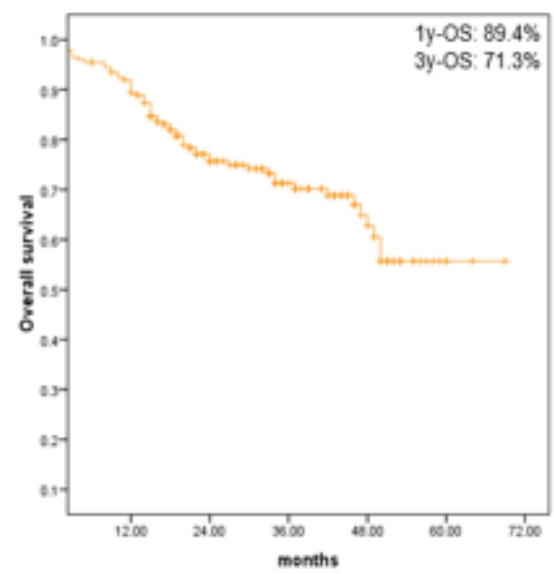

$\mathrm{C}$

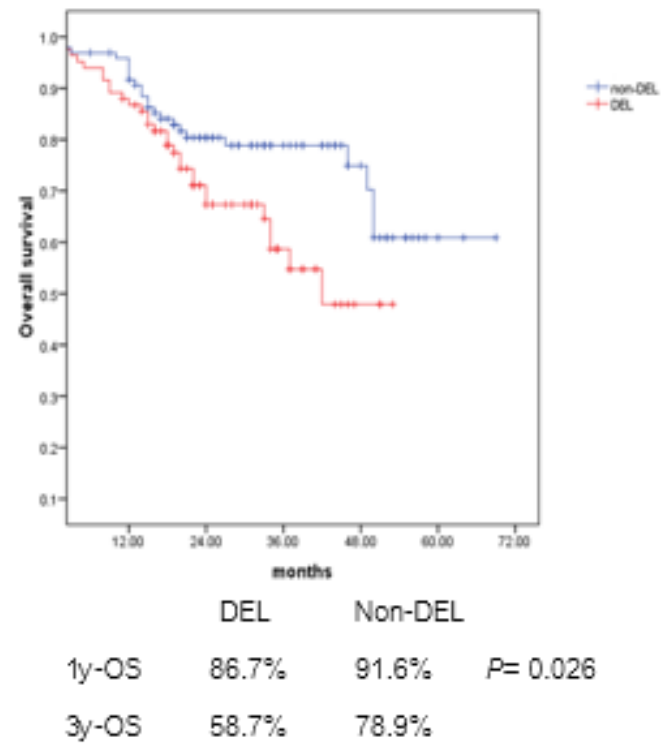

B

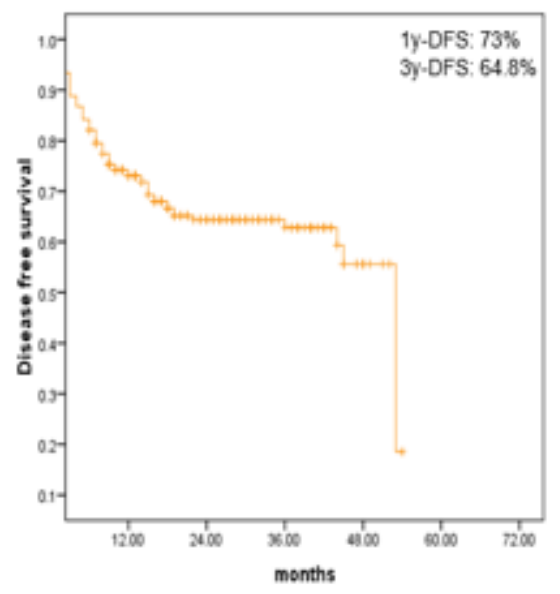

D

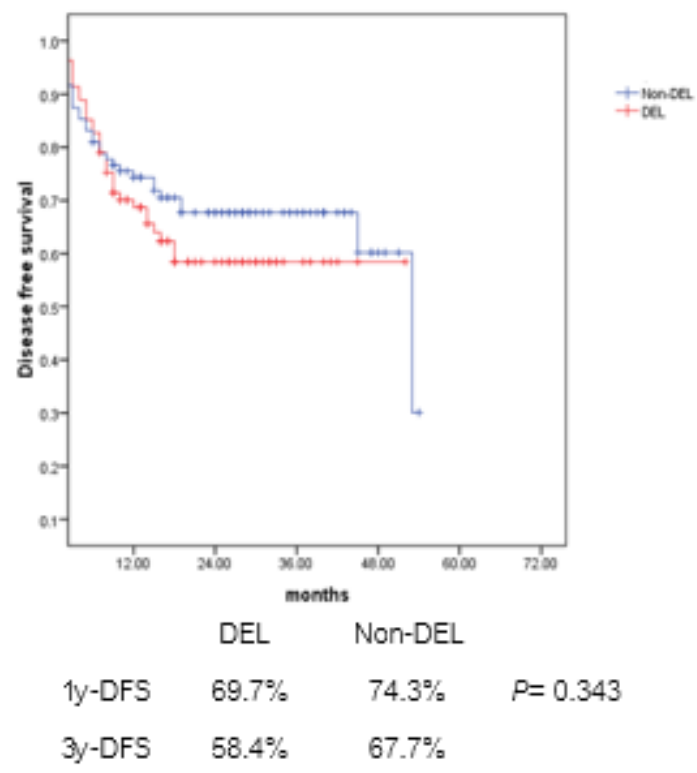

Figure 1. OS in DLBCL patients treated with rituximab based therapy (A), DFS in DLBCL patients treated with rituximab based therapy (B), OS in DEL patients treated with rituximab based therapy compared with that in non-DEL patients treated with rituximab based therapy (C), DFS in DEL patients treated with rituximab based therapy compared with that in non-DEL patients treated with rituximab based therapy (D).

significantly associated with dismal OS in DEL patients who were treated with both R-chemo and R-CHOP in multivariate Cox regression analysis, $\mathrm{p}=0.005$ (Rchemo) versus $p=0.01$ (R-CHOP) for high LDH level group and $p=0.034(\mathrm{R}$-chemo) versus $\mathrm{p}=0.031$ (RCHOP) for stage III-IV group. The results of the multivariate Cox regression analysis are shown in Table 4. DEL patients with high LDH levels and stage III-IV treated with R-CHOP had $3 y-O S$ of $41.8 \%$ and $37.6 \%$, respectively. In the non-DEL group, ECOG 3-4 was significantly associated with poorer OS in multivariate Cox analysis, $\mathrm{p}<0.001$.

In addition, the univariate analysis showed that the parameters significantly affecting DFS in both DEL and non-DEL patients were ECOG 3-4, stage III-IV, and high
IPI. Whereas high LDH levels, extranodal involvement $>1$, maximum tumor diameter (MTD) $>5$ or $7.5 \mathrm{~cm}$, and $\mathrm{BM}$ involvement were independent factors for poorer DFS in DEL patients. (Table 5) Nevertheless, in multivariate analysis, only high LDH levels $(p=0.011)$ and stage III-IV $(\mathrm{p}=0.035)$ were the independent factors affecting DFS in DEL patients receiving R-chemo. Stage III-IV $(p=0.028)$ was also associated with shorter DFS in DEL patients treated with R-CHOP in multivariate analysis. (Table 6) DEL patients with high LDH levels and stage III-IV treated with R-CHOP had 3y-DFS of $45.3 \%$ and $37.5 \%$, respectively. Factors affecting DFS in non-DEL patients receiving R-chemo were ECOG3-4 $(p<0.001)$, stage III-IV $(p=0.017)$ and MTD $)>5(p=$ $0.001)$ in multivariate analysis. 
A

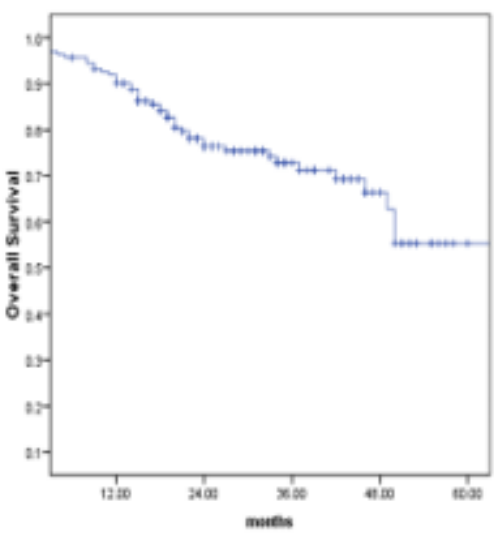

C

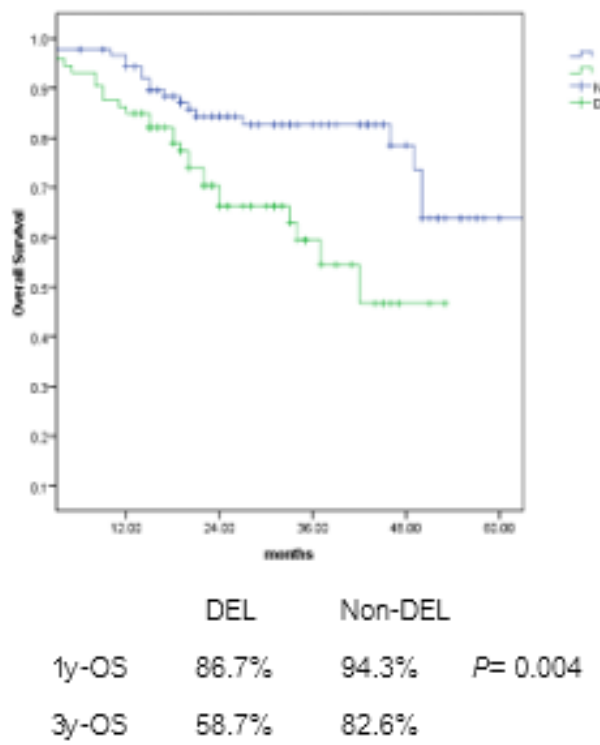

B

17-0s:919\%,

h-0s:72:5

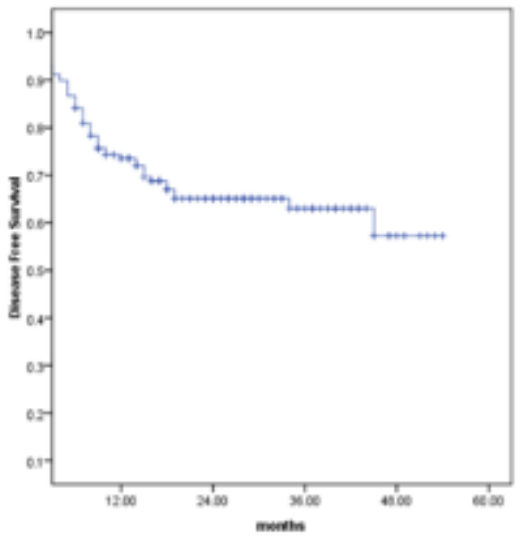

1y. DFs: 73.6 .

3y-DF5: $63 \%$

D

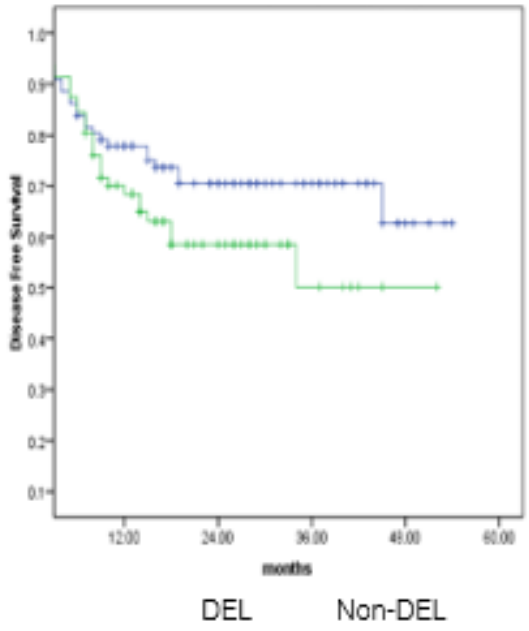

1y-DFS $\quad 68.4 \% \quad 84.9 \% \quad P=0.129$

3y-DFS $\quad 50.2 \% \quad 70.5 \%$

Figure 2. OS in DLBCL patients treated with R-CHOP (A), DFS in DLBCL patients treated with R-CHOP (B), OS in DEL patients treated with R-CHOP compared with that in non-DEL patients treated with R-CHOP $(\mathbf{C})$, DFS in DEL patients treated with R-CHOP compared with that in non-DEL patients treated with R-CHOP (D).

Table 3. Factors affecting overall survival in 184 DLBCL patients treated with rituximab based chemotherapy.

\begin{tabular}{|c|c|c|c|c|c|c|c|c|c|c|c|c|}
\hline \multirow[t]{2}{*}{ Factors } & \multicolumn{4}{|c|}{$\begin{array}{c}\text { DEL patients receiving } \\
\text { R-CHOP } \\
(\mathrm{N}=75) \\
\end{array}$} & \multicolumn{4}{|c|}{$\begin{array}{c}\text { DEL patients receiving } \\
\text { R-chemo } \\
(\mathbf{N}=\mathbf{8 7})\end{array}$} & \multicolumn{4}{|c|}{$\begin{array}{c}\text { Non-DEL patients receiving } \\
\text { R-chemo } \\
(\mathbf{N}=97)\end{array}$} \\
\hline & mOS (Mo) & $p$ & $1 y-O S$ & $3 y-O S$ & $\begin{array}{l}\text { mOS } \\
\text { (Mo) }\end{array}$ & $p$ & $1 y-O S$ & $3 y-O S$ & $\begin{array}{l}\text { mOS } \\
\text { (Mo) }\end{array}$ & $p$ & $1 y-O S$ & $3 y-O S$ \\
\hline \multicolumn{13}{|l|}{ Age (years) } \\
\hline$-<60$ & NR & 0.692 & 78.6 & 61.9 & NR & 0.492 & 86.4 & 62.1 & NR & 0.156 & 97.8 & 86 \\
\hline$-\geq 60$ & 37 & & 85.7 & 55.8 & 42 & & 86.9 & 56.9 & NR & & 86.1 & 72.5 \\
\hline \multicolumn{13}{|l|}{ ECOG } \\
\hline$-0-2$ & 42 & 0.045 & 86.4 & 60.5 & 42 & 0.004 & 88.4 & 61.3 & NR & $<0.001$ & 97.7 & 86.3 \\
\hline$-3-4$ & 8 & & 50 & NA & 14 & & 60 & 20 & 15 & & 55.6 & 0 \\
\hline \multicolumn{13}{|l|}{ LDH level } \\
\hline - Normal & NR & 0.001 & 90.9 & 90.9 & NR & $<0.001$ & 100 & 92.3 & NR & 0.841 & 95.3 & 79.5 \\
\hline - High & 24 & & 76.6 & 41.8 & 34 & & 80.3 & 40.8 & NR & & 90.6 & 78.1 \\
\hline Stage & & & & & & & & & & & & \\
\hline
\end{tabular}




\begin{tabular}{|c|c|c|c|c|c|c|c|c|c|c|c|c|}
\hline $\begin{array}{l}\text { - I- II } \\
\text { - III- IV }\end{array}$ & $\begin{array}{c}\text { NR } \\
24\end{array}$ & 0.001 & $\begin{array}{l}93.9 \\
75.7\end{array}$ & $\begin{array}{l}81.5 \\
37.6\end{array}$ & $\begin{array}{c}\text { NR } \\
24\end{array}$ & 0.001 & $\begin{array}{l}94.6 \\
80.4\end{array}$ & $\begin{array}{l}82.9 \\
40.2\end{array}$ & $\begin{array}{l}\text { NR } \\
\text { NR }\end{array}$ & $\begin{array}{r}0.2459 \\
9\end{array}$ & $\begin{array}{l}92.9 \\
90.6\end{array}$ & $\begin{array}{l}81.8 \\
76.6\end{array}$ \\
\hline $\begin{array}{l}\text { Extranodal involvement } \\
\text { - No } \\
\text { - Yes }\end{array}$ & $\begin{array}{l}\text { NR } \\
37\end{array}$ & 0.308 & $\begin{array}{l}85.7 \\
83.3\end{array}$ & $\begin{array}{l}69.4 \\
53.5\end{array}$ & $\begin{array}{l}\text { NR } \\
37\end{array}$ & 0.65 & $\begin{array}{l}89.1 \\
84.8\end{array}$ & $\begin{array}{l}69.1 \\
50.7\end{array}$ & $\begin{array}{l}\text { NR } \\
\text { NR }\end{array}$ & $\begin{array}{r}0.0739 \\
8\end{array}$ & $\begin{array}{l}97.4 \\
87.8\end{array}$ & $\begin{array}{l}88.4 \\
72.7\end{array}$ \\
\hline $\begin{array}{l}\text { Number of extranodal site } \\
\text { involvement } \\
-0-1 \\
->1\end{array}$ & $\begin{array}{c}\text { NR } \\
18\end{array}$ & $<0.001$ & $\begin{array}{l}88.1 \\
63.6\end{array}$ & $\begin{array}{l}65.5 \\
\text { NA }\end{array}$ & $\begin{array}{c}\text { NR } \\
18\end{array}$ & $<0.001$ & $\begin{array}{l}91.4 \\
69.2 \\
\end{array}$ & $\begin{array}{l}65.5 \\
15.8 \\
\end{array}$ & $\begin{array}{l}\text { NR } \\
\text { NR }\end{array}$ & $\begin{array}{r}0.8069 \\
8 \\
\end{array}$ & $\begin{array}{l}92.8 \\
84.6\end{array}$ & $\begin{array}{l}79.2 \\
76.9\end{array}$ \\
\hline $\begin{array}{l}\text { BM involvement } \\
\text { - No } \\
\text { - Yes }\end{array}$ & $\begin{array}{l}42 \\
22\end{array}$ & 0.17 & $\begin{array}{l}82,5 \\
83.3\end{array}$ & $\begin{array}{l}61.9 \\
\text { NA }\end{array}$ & $\begin{array}{l}42 \\
24\end{array}$ & 0.283 & $\begin{array}{l}84.9 \\
100\end{array}$ & $\begin{array}{l}61.4 \\
39.4\end{array}$ & $\begin{array}{c}\text { NR } \\
49\end{array}$ & $\begin{array}{r}0.0079 \\
8\end{array}$ & $\begin{array}{l}92.8 \\
84.6\end{array}$ & $\begin{array}{l}81.8 \\
59.8\end{array}$ \\
\hline $\begin{array}{l}\text { IPI } \\
\text { - Low } \\
\text { - Low- intermediate } \\
\text { - High- intermediate } \\
\text { - High }\end{array}$ & $\begin{array}{l}\text { NR } \\
42 \\
22 \\
15\end{array}$ & $<0.001$ & $\begin{array}{l}83.3 \\
82.1 \\
84.6 \\
60\end{array}$ & $\begin{array}{l}83.3 \\
57.3 \\
21.5 \\
\text { NA }\end{array}$ & $\begin{array}{l}\text { NR } \\
42 \\
22 \\
15\end{array}$ & $<0.001$ & $\begin{array}{l}100 \\
85.7 \\
92.3 \\
66.7\end{array}$ & $\begin{array}{l}100 \\
55.3 \\
21.5 \\
15\end{array}$ & $\begin{array}{c}\text { NR } \\
\text { NR } \\
\text { NR } \\
13\end{array}$ & $\begin{array}{r}0.0079 \\
9 \\
5\end{array}$ & $\begin{array}{c}97.3 \\
91 \\
94.7 \\
57.1\end{array}$ & $\begin{array}{l}88 \\
76.6 \\
77.3 \\
42.9\end{array}$ \\
\hline $\begin{array}{l}\text { Bulky lesion }(\mathrm{MTD} \geq 5 \mathrm{~cm}) \\
\text { - No } \\
\text { - Yes }\end{array}$ & $\begin{array}{l}37 \\
42\end{array}$ & 0.658 & $\begin{array}{l}88.2 \\
80.6\end{array}$ & $\begin{array}{l}51.4 \\
62.2\end{array}$ & $\begin{array}{l}37 \\
42\end{array}$ & 0.916 & $\begin{array}{l}89.7 \\
84.1\end{array}$ & $\begin{array}{l}57.7 \\
58.5\end{array}$ & $\begin{array}{l}\text { NR } \\
\text { NR }\end{array}$ & $\begin{array}{r}0.0619 \\
8\end{array}$ & $\begin{array}{l}96.3 \\
85.8\end{array}$ & $\begin{array}{l}86.3 \\
69.9\end{array}$ \\
\hline $\begin{array}{l}\text { Bulky lesion(MTD } \geq 7.5 \mathrm{~cm}) \\
-\mathrm{No} \\
- \text { Yes }\end{array}$ & $\begin{array}{c}42 \\
\text { NR }\end{array}$ & 0.45 & $\begin{array}{l}90.7 \\
74.1\end{array}$ & $\begin{array}{l}59.8 \\
54.9 \\
\end{array}$ & $\begin{array}{c}42 \\
\text { NR } \\
\end{array}$ & 0.282 & $\begin{array}{l}92 \\
78.8 \\
\end{array}$ & $\begin{array}{l}63.2 \\
50.4 \\
\end{array}$ & $\begin{array}{l}\text { NR } \\
\text { NR }\end{array}$ & $\begin{array}{r}0.3959 \\
8 \\
\end{array}$ & $\begin{array}{l}92.5 \\
89.7 \\
\end{array}$ & $\begin{array}{l}83 \\
69.9 \\
\end{array}$ \\
\hline $\begin{array}{l}\mathrm{COO} \\
-\mathrm{GCB} \\
- \text { Non-GCB }\end{array}$ & $\begin{array}{l}42 \\
22\end{array}$ & 0.026 & $\begin{array}{l}70.6 \\
84.8\end{array}$ & $\begin{array}{l}31.8 \\
65.1\end{array}$ & $\begin{array}{c}22 \\
\text { NR }\end{array}$ & 0.014 & $\begin{array}{l}70.6 \\
90\end{array}$ & $\begin{array}{l}31.8 \\
64.3\end{array}$ & $\begin{array}{l}\text { NR } \\
\text { NR }\end{array}$ & $\begin{array}{rr}0.74 \quad 9 \\
& 9\end{array}$ & $\begin{array}{l}90.1 \\
92.7\end{array}$ & $\begin{array}{l}78.6 \\
79.3\end{array}$ \\
\hline $\begin{array}{l}\text { DHL } \\
\text { - Non-DHL } \\
\text { - DHL } \\
\text { - Uninterpretable }\end{array}$ & $\begin{array}{c}\text { NR } \\
3 \\
42\end{array}$ & $<0.001$ & $\begin{array}{l}89.1 \\
50 \\
84.6\end{array}$ & $\begin{array}{l}70.9 \\
0^{7} \\
57.9\end{array}$ & $\begin{array}{c}\text { NR } \\
15 \\
42\end{array}$ & 0.001 & $\begin{array}{l}87.4 \\
66.7 \\
83.3\end{array}$ & $\begin{array}{l}68.6 \\
0 \\
55\end{array}$ & $\begin{array}{c}\mathrm{NR} \\
1 \\
\mathrm{NR}\end{array}$ & $\begin{array}{r}0.017 \\
1 \\
0 \\
1\end{array}$ & $\begin{array}{l}100 \\
0 \\
100\end{array}$ & $\begin{array}{l}83.3 \\
0 \\
100\end{array}$ \\
\hline $\begin{array}{l}\text { Ki-67 (\%) } \\
-<50 \\
-51-79 \\
-\geq 80\end{array}$ & $\begin{array}{c}- \\
\text { NR } \\
\text { NR }\end{array}$ & 0.658 & $\begin{array}{l}- \\
62.5 \\
86.9\end{array}$ & $\begin{array}{l}- \\
62.5 \\
55.6\end{array}$ & $\begin{array}{l}\text { NR } \\
\text { NR } \\
\text { NR }\end{array}$ & $0.274 \quad 1$ & $\begin{array}{l}100 \\
88.2 \\
87.8 \\
\end{array}$ & $\begin{array}{l}100 \\
67.3 \\
51.4 \\
\end{array}$ & $\begin{array}{l}21 \\
\text { NR } \\
\text { NR }\end{array}$ & 0.12 & $\begin{array}{l}100 \\
92.5 \\
89.7\end{array}$ & $\begin{array}{c}33.3 \\
76.5 \\
86\end{array}$ \\
\hline $\begin{array}{l}\text { RT } \\
- \text { No } \\
- \text { Yes }\end{array}$ & $\begin{array}{c}37 \\
\text { NR }\end{array}$ & 0.22 & $\begin{array}{l}83.7 \\
85.2\end{array}$ & $\begin{array}{l}51.9 \\
70.2\end{array}$ & $\begin{array}{c}37 \\
\text { NR }\end{array}$ & 0.222 & $\begin{array}{l}88.9 \\
86.2\end{array}$ & $\begin{array}{l}51.8 \\
71.9\end{array}$ & $\begin{array}{l}\text { NR } \\
\text { NR }\end{array}$ & 0.831 & $\begin{array}{l}89.5 \\
96.6\end{array}$ & $\begin{array}{l}81.6 \\
71.5\end{array}$ \\
\hline $\begin{array}{l}\text { Frontline RT }(\mathrm{MTD} \geq 5 \mathrm{~cm}) \\
\text { - No } \\
\text { - Frontline }\end{array}$ & $\begin{array}{c}42 \\
\text { NR }\end{array}$ & 0.362 & $\begin{array}{l}77.8 \\
83.3\end{array}$ & $\begin{array}{l}57.1 \\
68.2\end{array}$ & $\begin{array}{c}34 \\
\text { NR }\end{array}$ & 0.192 & $\begin{array}{l}83.3 \\
85\end{array}$ & $\begin{array}{l}57.9 \\
70.8\end{array}$ & $\begin{array}{c}50 \\
\text { NR }\end{array}$ & 0.961 & $\begin{array}{l}81.7 \\
93.3\end{array}$ & $\begin{array}{l}74.3 \\
60.5\end{array}$ \\
\hline $\begin{array}{l}\text { Frontline } \mathrm{RT}(\mathrm{MTD} \geq 7.5 \mathrm{~cm}) \\
\text { - No } \\
\text { - Frontline }\end{array}$ & $\begin{array}{c}20 \\
\text { NR }\end{array}$ & 0.431 & $\begin{array}{l}66.7 \\
80\end{array}$ & $\begin{array}{l}50 \\
61\end{array}$ & $\begin{array}{c}34 \\
\text { NR }\end{array}$ & 0.252 & $\begin{array}{l}75 \\
82.4\end{array}$ & $\begin{array}{l}27.5 \\
64.9\end{array}$ & $\begin{array}{l}\text { NR } \\
\text { NR }\end{array}$ & 0.364 & $\begin{array}{l}87.5 \\
92.3\end{array}$ & $\begin{array}{l}81.3 \\
52.7\end{array}$ \\
\hline $\begin{array}{l}\mathrm{COO} \\
-\mathrm{GCB} \\
\text { - Non-GCB }\end{array}$ & $\begin{array}{l}42 \\
22\end{array}$ & 0.026 & $\begin{array}{l}70.6 \\
84.8\end{array}$ & $\begin{array}{l}31.8 \\
65.1\end{array}$ & $\begin{array}{c}22 \\
\text { NR }\end{array}$ & 0.014 & $\begin{array}{l}70.6 \\
90\end{array}$ & $\begin{array}{l}31.8 \\
64.3\end{array}$ & $\begin{array}{l}\text { NR } \\
\text { NR }\end{array}$ & 0.74 & $\begin{array}{l}90.1 \\
92.7\end{array}$ & $\begin{array}{l}78.6 \\
79.3\end{array}$ \\
\hline $\begin{array}{l}\text { DHL } \\
\text { - Non-DHL } \\
\text { - DHL } \\
\text { - Uninterpretable }\end{array}$ & $\begin{array}{c}\text { NR } \\
3 \\
42\end{array}$ & $<0.001$ & $\begin{array}{l}89.1 \\
50 \\
84.6\end{array}$ & $\begin{array}{l}70.9 \\
0 \\
57.9\end{array}$ & $\begin{array}{c}\text { NR } \\
15 \\
42\end{array}$ & 0.001 & $\begin{array}{l}87.4 \\
66.7 \\
83.3\end{array}$ & $\begin{array}{l}68.6 \\
0 \\
55\end{array}$ & $\begin{array}{c}\mathrm{NR} \\
1 \\
\mathrm{NR}\end{array}$ & 0.017 & $\begin{array}{l}100 \\
0 \\
100\end{array}$ & $\begin{array}{l}83.3 \\
0 \\
100\end{array}$ \\
\hline $\begin{array}{l}\mathrm{Ki}-67(\%) \\
-<50 \\
-51-79 \\
-\geq 80\end{array}$ & $\begin{array}{c}- \\
\text { NR } \\
\text { NR }\end{array}$ & 0.658 & $\begin{array}{l}- \\
62.5 \\
86.9\end{array}$ & $\begin{array}{l}- \\
62.5 \\
55.6\end{array}$ & $\begin{array}{l}\text { NR } \\
\text { NR } \\
\text { NR }\end{array}$ & 0.274 & $\begin{array}{r}100 \\
88.2 \\
87.8\end{array}$ & $\begin{array}{c}100 \\
67.3 \\
51.4\end{array}$ & $\begin{array}{l}21 \\
\text { NR } \\
\text { NR }\end{array}$ & 0.12 & $\begin{array}{l}100 \\
92.5 \\
89.7\end{array}$ & $\begin{array}{c}33.3 \\
76.5 \\
86\end{array}$ \\
\hline
\end{tabular}




\begin{tabular}{|c|c|c|c|c|c|c|c|c|c|c|c|c|}
\hline $\begin{array}{l}\text { RT } \\
- \text { No } \\
\text { - Yes }\end{array}$ & $\begin{array}{c}37 \\
\text { NR }\end{array}$ & 0.22 & $\begin{array}{l}83.7 \\
85.2\end{array}$ & $\begin{array}{l}51.9 \\
70.2\end{array}$ & $\begin{array}{c}37 \\
\text { NR }\end{array}$ & 0.222 & $\begin{array}{l}88.9 \\
86.2\end{array}$ & $\begin{array}{l}51.8 \\
71.9\end{array}$ & $\begin{array}{l}\text { NR } \\
\text { NR }\end{array}$ & 0.831 & $\begin{array}{l}89.5 \\
96.6\end{array}$ & $\begin{array}{l}81.6 \\
71.5\end{array}$ \\
\hline $\begin{array}{l}\text { Frontline RT }(\mathrm{MTD} \geq 5 \mathrm{~cm}) \\
\text { - No } \\
\text { - Frontline }\end{array}$ & $\begin{array}{c}42 \\
\text { NR }\end{array}$ & 0.362 & $\begin{array}{l}77.8 \\
83.3\end{array}$ & $\begin{array}{l}57.1 \\
68.2\end{array}$ & $\begin{array}{c}34 \\
\text { NR }\end{array}$ & 0.192 & $\begin{array}{l}83.3 \\
85\end{array}$ & $\begin{array}{l}57.9 \\
70.8\end{array}$ & $\begin{array}{c}50 \\
\text { NR }\end{array}$ & 0.961 & $\begin{array}{l}81.7 \\
93.3\end{array}$ & $\begin{array}{l}74.3 \\
60.5\end{array}$ \\
\hline $\begin{array}{l}\text { Frontline RT }(M T D \geq 7.5 \mathrm{~cm}) \\
\text { - No } \\
\text { - Frontline }\end{array}$ & $\begin{array}{r}20 \\
\text { NR } \\
\end{array}$ & 0.431 & $\begin{array}{l}66.7 \\
80 \\
\end{array}$ & $\begin{array}{l}50 \\
61 \\
\end{array}$ & $\begin{array}{r}34 \\
\text { NR } \\
\end{array}$ & 0.252 & $\begin{array}{l}75 \\
82.4 \\
\end{array}$ & $\begin{array}{r}27.5 \\
64.9 \\
\end{array}$ & $\begin{array}{l}\text { NR } \\
\text { NR }\end{array}$ & 0.364 & $\begin{array}{r}87.5 \\
92.3 \\
\end{array}$ & $\begin{array}{l}81.3 \\
52.7 \\
\end{array}$ \\
\hline
\end{tabular}

Table 4. Multivariate Cox regression analysis of factors contributing to overall survival of DE-DLBCL patients treated with R-chemo and RCHOP.

\begin{tabular}{|c|c|c|c|c|c|c|c|c|}
\hline \multirow[t]{3}{*}{ Parameters } & \multicolumn{4}{|c|}{ R-chemo } & \multicolumn{4}{|c|}{$\mathrm{R}-\mathrm{CHOP}$} \\
\hline & \multirow{2}{*}{$\begin{array}{l}\text { OS } \\
(P)\end{array}$} & \multirow{2}{*}{$\begin{array}{c}\mathrm{OS} \\
(\mathrm{HR})\end{array}$} & \multicolumn{2}{|c|}{$95 \% \mathrm{CI}$} & \multirow{2}{*}{$\begin{array}{l}\mathrm{OS} \\
(P)\end{array}$} & \multirow{2}{*}{$\begin{array}{l}\text { OS } \\
\text { (HR) }\end{array}$} & \multicolumn{2}{|c|}{$95 \% \mathrm{CI}$} \\
\hline & & & Lower & Upper & & & Lower & Upper \\
\hline Age $\geq 60$ years & 0.113 & 2.412 & 0.814 & 7.155 & 0.146 & 2.393 & 0.737 & 7.763 \\
\hline ECOG 3-4 & 0.313 & 1.814 & 0.570 & 5.778 & 0.476 & 1.614 & 0.433 & 6.014 \\
\hline High LDH levels & 0.005 & 6.028 & 1.700 & 21.375 & 0.01 & 5.635 & 1.525 & 20.827 \\
\hline Stage III-IV & 0.034 & 3.496 & 1.101 & 11.097 & 0.031 & 3.62 & 1.128 & 11.62 \\
\hline $\begin{array}{l}\text { Extranodal involvement> } \\
1 \text { site }\end{array}$ & 0.086 & 2.238 & 0.893 & 5.611 & 0.068 & 2.412 & 0.936 & 6.215 \\
\hline GCB & 0.884 & 0.933 & 0.365 & 2.386 & 0.695 & 0.823 & 0.310 & 2.182 \\
\hline
\end{tabular}

Table 5. Factors affecting disease free survival in 184 DLBCL patients treated with rituximab based chemotherapy.

\begin{tabular}{|c|c|c|c|c|c|c|c|c|c|c|c|c|}
\hline \multirow[t]{2}{*}{ Factors } & \multicolumn{4}{|c|}{$\begin{array}{c}\text { DEL patients receiving } \\
\text { R-CHOP } \\
(\mathrm{N}=75) \\
\end{array}$} & \multicolumn{4}{|c|}{$\begin{array}{c}\text { DEL patients receiving } \\
\text { R-chemo } \\
(\mathbf{N}=\mathbf{8 7}) \\
\end{array}$} & \multicolumn{4}{|c|}{$\begin{array}{c}\text { Non-DEL patients receiving } \\
\text { R-chemo } \\
(\mathbf{N}=97) \\
\end{array}$} \\
\hline & $\begin{array}{c}\text { mDFS } \\
\text { (Mo) }\end{array}$ & $p$ & $1 y-D F$ & 3y-DFS & $\begin{array}{c}\text { mDFS } \\
\text { (Mo) }\end{array}$ & $p$ & $1 \mathrm{y}-\mathrm{DF}$ & $3 y-D F S$ & $\begin{array}{c}\text { mDFS } \\
\text { (Mo) }\end{array}$ & $p$ & 1y-DFS & 3y-DFS \\
\hline \multicolumn{13}{|l|}{ Age (years) } \\
\hline$-<60$ & NR & 0.489 & 69.2 & 69.2 & NR & 0.762 & 71.9 & 68.3 & 45 & 0.211 & 73.4 & 73.4 \\
\hline$-\geq 60$ & 34 & & 68.9 & 44.9 & 44 & & 70.8 & 65.5 & 53 & & 67.2 & 56.8 \\
\hline \multicolumn{13}{|l|}{ ECOG } \\
\hline$-0-2$ & NR & 0.091 & 70 & 52.3 & 44 & 0.002 & 73.7 & 70.4 & 53 & $<0.001$ & 75.3 & 68.9 \\
\hline$-3-4$ & 8 & & 25 & NA & 3 & & 25 & 0 & 3 & & 20 & NA \\
\hline \multicolumn{13}{|l|}{ LDH level } \\
\hline - Normal & NR & 0.008 & 86.5 & 64.9 & 44 & 0.001 & 88 & 44 & 53 & 0.093 & 75 & 75 \\
\hline - High & 18 & & 60.4 & 45.3 & NR & & 60.4 & 51.7 & 45 & & 66.1 & 54.5 \\
\hline \multicolumn{13}{|l|}{ Stage } \\
\hline - I- II & NR & $<0.001$ & 90.9 & 61.4 & NR & $<0.001$ & 86.6 & 86.6 & NR & 0.004 & 85.2 & 78.4 \\
\hline - III- IV & 12 & & 48.7 & 37.5 & 16 & & 55.2 & 48.9 & 45 & & 81.7 & 50.7 \\
\hline \multicolumn{13}{|c|}{ Extranodal involvement } \\
\hline - No & NR & 0.097 & 80.7 & 50.2 & NR & 0.22 & 75.1 & 75.1 & NR & 0.077 & 80.5 & 76 \\
\hline - Yes & 18 & & 61.5 & 48.9 & 44 & & 67 & 62.1 & 45 & & 83 & 60.5 \\
\hline \multicolumn{13}{|c|}{$\begin{array}{l}\text { Number of extranodal site } \\
\text { involvement }\end{array}$} \\
\hline$-0-1$ & NR & $<0.001$ & 75.4 & 56.6 & NR & $<0.001$ & 76.2 & 72.8 & 45 & 0.570 & 71.2 & 63.2 \\
\hline$->1$ & 7 & & 34.1 & NA & 3 & & 41.7 & 21.8 & 53 & & 60 & 60 \\
\hline \multicolumn{13}{|l|}{ BM involvement } \\
\hline - No & NR & 0.008 & 72.1 & 53.9 & 44 & 0.022 & 73.4 & 71.7 & 53 & 0.119 & 85.5 & 69.2 \\
\hline - Yes & 6 & & 42.9 & NA & 10 & & 50 & 16.7 & 15 & & 50.3 & 42 \\
\hline \multicolumn{13}{|l|}{ IPI } \\
\hline - Low & NR & $<0.001$ & 94.7 & 71.1 & NR & $<0.001$ & 93.3 & 93.3 & NR & 0.004 & 86.4 & 86.4 \\
\hline - Low- intermediate & NR & & 73.2 & 73.2 & NR & & 67.7 & 63.2 & 45 & & 68.7 & 61.2 \\
\hline - High- intermediate & 12 & & 42.2 & 28.1 & 15 & & 56.1 & 44.9 & 22 & & 58.8 & 44.1 \\
\hline
\end{tabular}




\begin{tabular}{|c|c|c|c|c|c|c|c|c|c|c|c|c|}
\hline \multirow{2}{*}{$\begin{array}{l}\text { - High } \\
\text { Bulky lesion }(M T D \geq 5 \mathrm{~cm})\end{array}$} & \multicolumn{2}{|l|}{7} & \multirow[t]{2}{*}{40} & \multirow[t]{2}{*}{ NA } & \multicolumn{2}{|l|}{4} & \multirow[t]{2}{*}{16.7} & \multirow[t]{2}{*}{0} & \multicolumn{2}{|l|}{7} & \multirow[t]{2}{*}{46.2} & \multirow[t]{2}{*}{36.9} \\
\hline & & & & & & & & & & & & \\
\hline - No & 34 & 0.274 & 64.3 & 27.5 & NR & 0.017 & 80.5 & 77.6 & 53 & 0.223 & 78.1 & 66.4 \\
\hline - Yes & NR & & 73.8 & 62.4 & NR & & 59.9 & 53.3 & 45 & & 64.1 & 58 \\
\hline Bulky lesion(MTD $\geq 7.5 \mathrm{~cm}$ ) & & & & & & & & & & & & \\
\hline - No & 34 & 0.903 & 66.9 & 45.3 & 44 & 0.009 & 76.7 & 74.6 & 53 & 0.360 & 71.3 & 65 \\
\hline - Yes & NR & & 72.7 & 55.7 & 15 & & 56.5 & 45.2 & 45 & & 66.3 & 57.6 \\
\hline $\mathrm{COO}$ & & & & & & & & & & & & \\
\hline - GCB & NR & 0.085 & 72.7 & 54.1 & NR & 0.576 & 73.4 & 67 & 53 & 0.877 & 70.9 & 62.3 \\
\hline - Non-GCB & 14 & & 57.8 & 37.1 & 44 & & 66.5 & 66.5 & 45 & & 66.7 & 63.3 \\
\hline DHL & & & & & & & & & & & & \\
\hline - Non-DHL & NR & 0.012 & 81.9 & 57.4 & NR & 0.02 & 81.6 & 51 & NR & 0.445 & 83.3 & 62.5 \\
\hline - DHL & 5 & & 0 & 0 & 5 & & 0 & 0 & - & & - & - \\
\hline - Uninterpretable & NR & & 77.4 & 61.9 & NR & & 75.2 & 59.1 & NR & & 100 & 100 \\
\hline Ki-67 (\%) & & & & & & & & & & & & \\
\hline$-\leq 50$ & NR & 0.791 & - & - & NR & 0.884 & 66.7 & 66.7 & 1 & 0.005 & 0 & 0 \\
\hline$-51-79$ & NR & & 71.4 & 0 & NR & & 68.8 & 61.1 & NR & & 78 & 78 \\
\hline$-\geq 80$ & NR & & 68.2 & 58.4 & 44 & & 70 & 68 & 53 & & 69.2 & 60.2 \\
\hline RT & & & & & & & & & & & & \\
\hline - No & 34 & 0.084 & 61.3 & 34.5 & 44 & 0.813 & 70.3 & 65.4 & 53 & 0.34 & 72.6 & 65.2 \\
\hline - Yes & NR & & 81.3 & 69.6 & NR & & 72.8 & 68.7 & NR & & 59.1 & 54.2 \\
\hline Frontline RT $(M T D \geq 5 \mathrm{~cm})$ & & & & & & & & & & & & \\
\hline - No & NR & 0.439 & 64.7 & 57.5 & 15 & 0.468 & 52.9 & 46.3 & 45 & 0.436 & 66.4 & 61.7 \\
\hline - Frontline & NR & & 83 & 67 & NR & & 66 & 59.4 & 14 & & 58.3 & 48.6 \\
\hline Frontline RT $(M T D \geq 7.5 \mathrm{~cm})$ & & & & & & & & & & & & \\
\hline - No & NR & 0.479 & 63.6 & NA & 15 & 0.841 & 57.1 & 38.1 & 45 & 0.350 & 70.6 & 62.7 \\
\hline - Frontline & NR & & 79.4 & 58.8 & 15 & & 56.2 & 48.2 & 14 & & 58.3 & 48.6 \\
\hline
\end{tabular}

Table 6. Multivariate Cox regression analysis of factors contributing to disease free survival of DE-DLBCL patients treated with R-chemo and R-CHOP.

\begin{tabular}{|c|c|c|c|c|c|c|c|c|}
\hline \multirow[t]{3}{*}{ Parameters } & \multicolumn{4}{|c|}{ R-chemo } & \multicolumn{4}{|c|}{$\mathrm{R}-\mathrm{CHOP}$} \\
\hline & \multirow[t]{2}{*}{$\operatorname{DFS}(P)$} & \multirow{2}{*}{$\begin{array}{l}\text { DFS } \\
\text { (HR) }\end{array}$} & \multicolumn{2}{|c|}{$95 \% \mathrm{CI}$} & \multirow{2}{*}{$\begin{array}{c}\text { DFS } \\
(P)\end{array}$} & \multirow{2}{*}{$\begin{array}{l}\text { DFS } \\
\text { (HR) }\end{array}$} & \multicolumn{2}{|c|}{$95 \% \mathrm{CI}$} \\
\hline & & & Lower & Upper & & & Lower & Upper \\
\hline Age $\geq 60$ years & 0.625 & 1.283 & 0.472 & 3.483 & 0.179 & 2.276 & 0.685 & 7.565 \\
\hline ECOG 3-4 & 0.203 & 2.229 & 0.649 & 7.655 & 0.364 & 1.942 & 0.463 & 8.147 \\
\hline High LDH levels & 0.011 & 5.099 & 1.442 & 18.035 & 0.050 & 3.125 & 0.999 & 9.775 \\
\hline Stage III-IV & 0.035 & 3.279 & 1.084 & 9.915 & 0.028 & 3.649 & 1.149 & 11.585 \\
\hline $\begin{array}{l}\text { Extranodal involvement }>1 \\
\text { site }\end{array}$ & 0.419 & 1.466 & 0.580 & 3.706 & 0.379 & 1.594 & 0.564 & 4.506 \\
\hline GCB & 0.650 & 1.225 & 0.510 & 2.943 & 0.868 & 1.083 & 0.422 & 2.776 \\
\hline BM involvement & 0.619 & 1.305 & 0.457 & 3.728 & 0.247 & 1.953 & 0.629 & 6.064 \\
\hline $\mathrm{MTD} \geq 5 \mathrm{~cm}$ & 0.771 & 0.837 & 0.247 & 2.819 & 0.474 & 0.620 & 0.167 & 2.294 \\
\hline $\mathrm{MTD} \geq 7.5 \mathrm{~cm}$ & 0.634 & 0.746 & 0.224 & 2.489 & 0.696 & 0.765 & 0.199 & 2.936 \\
\hline
\end{tabular}

DEL with BCL6 expression had no significant therapy, $(p=0.959)$. difference in 3y-OS and 3y-DFS compared with those in DEL with BCL6 negative DLBCL $(71.3 \%$ versus $68.8 \%$, $\mathrm{p}=0.729$ and $60.7 \%$ versus $62.5 \%, \mathrm{p}=1.00$, respectively). Patients receiving R-DA-EPOCH had 1y-OS of $91.67 \%$ and $3 \mathrm{y}-\mathrm{OS}$ of $64.3 \%$, whereas $1 \mathrm{y}-\mathrm{OS}$ and $3 \mathrm{y}-\mathrm{OS}$ in patients receiving R-CHOP were $86.7 \%$ and $58.7 \%$, respectively $(p=0.497)$. The $1 y-D F S$ of $75 \%$ and $3 y-$ DFS of $60 \%$ following R-DA-EPOCH therapy, and 1yDFS of $68.4 \%$ and $3 y$-DFS of $50.2 \%$ following R-CHOP

Discussion. In this study, the frequency of DEL was $46 \%$ of DLBCL patients, and 77\% of DE-DLBCL was nonGCB subtype, and the prevalence of both DEL and nonGCB with DE was higher than those reported in the previous studies. ${ }^{10-13}$ Therefore, DEL is commonly found in non-GCB compared to GCB subtype. ${ }^{11-13}$ Nevertheless, non-DEL DLBCL was also often observed in non-GCB in our study $(60 \%)$ which was in contrast to 
the previous report that non-DEL was commonly found in GCB patients. ${ }^{11}$ In addition, DHL had an extremely low prevalence in our cohort (3.4\%), and the prevalence of DEL and DHL differed from that in previous studies, which might be attributable to the fact that our study was a single-center retrospective study conducted at an academic tertiary referral hospital and we only recruited DLBCL patients undergoing DLBCL treatment at our center. Patients with DEL had significantly older age, high LDH levels and high Ki-67 proliferation than those with non-DEL, in line with the clinical manifestations in patients with DEL in previous reports. However, only small population of our DEL patients had poor performance status, high IPI or multiple extranodal sites of involvement. ${ }^{11}$ GCB with DEL subtype had lower CR rate than that in non-GCB with DE patients which might be associated with the small number of GCB with DE patients receiving $\mathrm{R}$-chemo (21 patients).

Among patients who received R-CHOP therapy, our study demonstrated that the DFS rate in non-DEL patients was higher than that in DEL patients with a $16.5 \%$ difference in DFS at 1 year $(84.9 \%$ versus $68.4 \%)$ and $20 \%$ difference in DFS at three years $(70.5 \%$ versus $50.2 \%$ ), even though the result was not statistically significant between these groups. This result is consistent with the fact that DE-DLBCL is more aggressive than the non-DEL subtype. ${ }^{3,6,10-16}$ Conversely, the OS rate was significantly lower in the DEL group than in the non-DEL group. We found that $94 \%$ of $R / R$ DE-DLBCL patients did not respond to salvage chemotherapy and died from progressive disease (PD). Meanwhile, $22 \%$ of patients with $\mathrm{R} / \mathrm{R}$ non-DEL achieved $C R$ after salvage therapy and remained alive at the end of the study. Similar results were observed in patients who received R-chemo, and a lower 3-year OS rate was observed in patients with DEL than in patients with non-DEL $(58.7 \%$ vs. $78.9 \%)$, and the cause of significantly shorter OS in DEL patients was PD after salvage therapy.

Conversely, there was no difference in DFS between the DEL and non-DEL arms among patients treated with receiving R-chemo at $1(69.7 \%$ versus $74.3 \%)$ and three years $(58.4 \%$ versus $66.7 \%)$. The possible cause of slightly higher DFS rates at 1 and 3 years in the non-DEL patients than in the DEL group might be the higher rate of treatment with R-DAEPOCH in the DEL group. Furthermore, our data also illustrated that both OS and DFS were markedly decreased in patients with DEL within two years after diagnosis, confirming that DEL is an aggressive lymphoma and did not respond to salvage therapy. In previous studies, the 2-year OS and PFS rates in patients with DEL treated with R-CHOP were approximately $50 \%-70 \%$ and $50 \%-54 \%$, respectively, ${ }^{6,11}$ and the 5-year OS and PFS rates were $30 \%-36 \%$ and $27 \%-32 \%$, respectively. ${ }^{9,10}$ Similarly, the 2 -year OS and DFS rates among patients with DEL treated with R-
CHOP in this study were $66.3 \%$ and $58.5 \%$, respectively (Figure 2). However, the study's median duration of follow-up time was only two years, and we also lacked data on molecular features in our DLBCL patients. Therefore a long-term follow-up (5 years) and further study on the molecular biology in our DLBCL patients are needed.

Factors affecting OS and DFS in DE-DLBCL patients were ECOG 3-4, high LDH levels, extranodal involvement $>1$ site, stage III-IV and high-intermediate/ high IPI. Nevertheless, only high LDH levels and stage III-IV were independent factors for OS in the DEL patients treated with both R-chemo and R-CHOP in multivariate analysis, in line with previous studies..$^{11,12,14}$ High LDH levels and stage III-IV were the independent factors affecting DFS in DEL patients receiving Rchemo, whereas stage III-IV was associated with shorter DFS in DEL patients treated with R-CHOP in multivariate analysis. ECOG 3-4, high LDH levels, extranodal involvement $>1$ site, stage III-IV and highintermediate/ high IPI were also significantly associated with lower CR rate in DEL patients. There was no significant difference in OS and DFS rate between DEL patients who received R-CHOP (75 patients) and R-DAEPOCH (12 patients), as previously reported in a retrospective study from MD Anderson; ${ }^{15}$ however, the limitation of our survival analysis was a small number of patients treated with R-DA-EPOCH since the major population of DEL patients were older patients which could not tolerate high-intensity chemotherapy. In the group of DEL patients, non-GCB patients had significantly better OS than GCB-DLBCL patients in the univariate analysis; nevertheless, the median age of GCB patients was 70 years (range, 48-86 years) and all of whom receiving R-CHOP therapy with $53 \%$ of recorded deaths from disease progression. Frontline rituximabbased chemotherapy combined with RT did not show benefit on DFS and OS in our DEL patients with either MTD $>5$ or $7.5 \mathrm{~cm}$. In the study of Japanese patients with relapsed/refractory DEL, poor outcomes in OS and EFS were seen even in patients who underwent allogeneic stem cell transplantation..$^{17}$ Although FISH is a standard test for diagnosis of DHL, it is expensive and timeconsuming; therefore, we performed FISH testing for MYC/BCL2/BCL6 rearrangement only in DLBCL patients with MYC protein expression $>40 \%$, since the report of Zhang et al. illustrated that MYC translocation was found only in DLBCL with MYC protein expression and the other previous studies showed that MYC protein expression $>50 \%$ and $>70 \%$ were predicted to have a rearrangement of MYC gene. ${ }^{14,17,18}$ The limitations of our study were the retrospective study population, the small number of DE-DLBCL patients receiving R-DAEPOCH therapy, and poor FISH quality on formalinfixed paraffin-embedded tissues that have been stored for a long period. Therefore, it is impossible to draw 
definitive conclusions regarding the best treatment for these patients.

Conclusions. A high incidence of double-expressor lymphoma was observed in this study, especially in patients aged 60 years or older and non-GCB subtype. Patients with DEL showed dismal DFS and OS. Poor performance status, high LDH and extranodal involvement $>1$ site, DHL, high IPI, and stage III-IV were significantly associated with dismal OS and DFS in DE-DLBCL patients.

Acknowledgments. We would like to thank all patients who participated in the study. We want to thank Ramathibodi Comprehensive Cancer Center, Ramathibodi Hospital, Mahidol University for providing research funding.

\section{References:}

1. Bunworasate U, Siritanaratanakul N, Khuhapinant A, Lekhakula A, Rujirojindakul P, Sirijerachai C, Chansung K, Suwanban T, Chuncharunee S, Niparuck P, Nawarawong W, Norasetthada L, Kanitsap $\mathrm{N}$, Mongkonsritragoon $\mathrm{W}$, Numbenjapon $\mathrm{T}$, Prayongratana $\mathrm{K}$, Pornvipavee R, Intragumtornchai $\mathrm{T}$. A nationwide prospective multicenter study of clinical features and outcomes of non-Hodgkin lymphoma in Thailand: an analysis of 939 cases. 2011:2064-64. https://doi.org/10.1182/blood.V118.21.2064.2064

2. Hans CP, Weisenburger DD, Greiner TC, Gascoyne RD, Delabie J, Ott G, Müller-Hermelink HK, Campo E, Braziel RM, Jaffe ES, Pan Z, Farinha P, Smith LM, Falini B, Banham AH, Rosenwald A, Staudt LM, Connors JM, Armitage JO, Chan WC. Confirmation of the molecular classification of diffuse large B-cell lymphoma by immunohistochemistry using a tissue microarray. Blood. 2004;103(1):275-82. https://doi.org/10.1182/blood-2003-05-1545 PMid:14504078

3. Aggarwal A, Rafei H, Alakeel F, NafezFinianos A, LingLiu M, Bahesh E, LAscensao J, Mobarek D. Outcome of Patients with Double-Expressor Lymphomas (DELs) Treated with R-CHOP or R-EPOCH. Blood. 2016;128:5396.

https://doi.org/10.1182/blood.V128.22.5396.5396

4. Swerdlow SH, Campo E, Pileri SA, Harris NL, Stein H, Siebert R, Advani R, Ghielmini M, Salles GA, Zelenetz AD, Jaffe ES. The 2016 revision of the World Health Organization classification of lymphoid neoplasms. Blood. 2016;127:2375-90.

https://doi.org/10.1182/blood-2016-01-643569 PMid:26980727 PMCid:PMC4874220

5. Nowakowski GS, Laplant BR, Macon WR, Reeder CB, Foran JM, Nelson GD, Thompson CA, Rivera CE, Inwards DJ, Micallef IN, Johnston PB, Porrata LF, Ansell SM, Gascoyne RD, Habermann TM, Witzig TE. Lenalidomide Combined with R-CHOP (R2CHOP) overcomes negative prognostic impact of $\mathrm{ABC}$ molecular subtype in newly diagnosed diffuse large B-cell lymphoma. Blood. 2016;128:3035. https://doi.org/10.1182/blood.V128.22.3035.3035

6. Dodero A, Guidetti A, Tucci A, Barretta F, Novo M, Devizzi L, Re A, Passi A, Pellegrinelli A, Pruneri G, Miceli R, Testi A, Pennisi M, Di Chio MC, Matteucci P, Carniti C, Facchetti F, Rossi G, Corradini P. Doseadjusted EPOCH plus rituximab improves the clinical outcome of young patients affected by double expressor diffuse large B-cell lymphoma. Leukemia. 2019;33(4):1047-51.

https://doi.org/10.1038/s41375-018-0320-9 PMid:30631117 PMCid:PMC6756077

7. Hans CP, Weisenburger DD, Greiner TC, Gascoyne RD, Delabie J, Ott G, Müller-Hermelink HK, Campo E, Braziel RM, Jaffe ES, Pan Z, Farinha P, Smith LM, Falini B, Banham AH, Rosenwald A, Staudt LM, Connors JM, Armitage JO, Chan WC. Confirmation of the molecular classification of diffuse large B-cell lymphoma by immuno-histochemistry using a tissue microarray. Blood. 2004;103:275-82. https://doi.org/10.1182/blood-2003-05-1545 PMid:14504078
Funding. This work was supported by Ramathibodi Comprehensive Cancer Center, Ramathibodi Hospital, Mahidol University.

Ethics approval and consent to participate. This retrospective study was approved by the Local Ethics Committee on Human Rights related to research involving human subjects at Ramathibodi Hospital, Mahidol University.

Authors' Contributions. SR collected clinical data, FISH testing results, analyzed the data, and wrote the manuscript. PB performed the histological examination. PC, TP, SP, SP, KB, PW, PA, AU, SC carried out the experiment. PN designed the study, analyzed the data, and edited the manuscript. All authors read and approved the final manuscript.

8. Choi WW, Weisenburger DD, Greiner TC, Piris MA, Banham AH, Delabie J, Braziel RM, Geng H, Iqbal J, Lenz G, Vose JM, Hans CP, Fu K, Smith LM, Li M, Liu Z, Gascoyne RD, Rosenwald A, Ott G, Rimsza LM, Campo E, Jaffe ES, Jaye DL, Staudt LM, Chan WC. A new immunostain algorithm classifies diffuse large B-cell lymphoma into molecular subtypes with high accuracy. Clin Cancer Res. 2009;15(17): 5494-502. https://doi.org/10.1158/1078-0432.CCR-09-0113

PMid:19706817 PMCid:PMC7289055

9. Schmitz N, Zeynalova S, Nickelsen M, Kansara R, Villa D, Sehn LH, Glass B, Scott DW, Gascoyne RD, Connors JM, Ziepert M, Pfreundschuh M, Loeffler M, Savage KJ. CNS International Prognostic Index: A Risk Model for CNS Relapse in Patients With Diffuse Large B-Cell Lymphoma Treated With R-CHOP. J Clin Oncol. 2016;34(26):3150-6. https://doi.org/10.1200/JCO.2015.65.6520 PMid:27382100

10. Johnson NA, Slack GW, Savage KJ, Connors JM, Ben-Neriah S, Rogic S, Scott DW, Tan KL, Steidl C, Sehn LH, Chan WC, Iqbal J, Meyer PN, Lenz G, Wright G, Rimsza LM, Valentino C, Brunhoeber P, Grogan TM, Braziel RM, Cook JR, Tubbs RR, Weisenburger DD, Campo E, Rosenwald A, Ott G, Delabie J, Holcroft C, Jaffe ES, Staudt LM, Gascoyne RD. Concurrent expression of MYC and BCL2 in diffuse large B-cell lymphoma treated with rituximab plus cyclophosphamide, doxorubicin, vincristine, and prednisone. J Clin Oncol. 2012;30:3452-9. https://doi.org/10.1200/JCO.2011.41.0985 PMid:22851565 PMCid:PMC3454768

11. Hu S, Xu-Monette ZY, Tzankov A, Green T, Wu L, Balasubramanyam A Liu WM, Visco C, Li Y, Miranda RN, Montes-Moreno S, Dybkaer K, Chiu A, Orazi A, Zu Y, Bhagat G, Richards KL, Hsi ED, Choi WW, Zhao X, van Krieken JH, Huang Q, Huh J, Ai W, Ponzoni M, Ferreri AJ, Zhou F, Slack GW, Gascoyne RD, Tu M, Variakojis D, Chen W, Go RS, Piris MA, Møller MB, Medeiros LJ, Young KH. MYC/BCL2 protein coexpression contributes to the inferior survival of activated B-cell subtype of diffuse large B-cell lymphoma and demonstrates highrisk gene expression signatures: a report from the International DLBCL RituximabCHOP Consortium Program. Blood. 2013;121:4021-31.

https://doi.org/10.1182/blood-2012-10-460063 PMid:23449635 PMCid:PMC3709650

12. Riedell PA, Smith SMJC. Double hit and double expressors in lymphoma: definition and treatment. 2018;124(24):4622-32. https://doi.org/10.1002/cncr.31646 PMid:30252929

13. Liu Y, Barta SK. Diffuse large B-cell lymphoma: 2019 update on diagnosis, risk stratification, and treatment. Am J Hematol. 2019;94:60416. https://doi.org/10.1002/ajh.25460 PMid:30859597

14. Green TM, Young KH, Visco C, Xu-Monette ZY, Orazi A, Go RS, Nielsen O, Gadeberg OV, Mourits-Andersen T, Frederiksen M, Pedersen LM, Møller MB. Immunohistochemical double-hit score is a strong predictor of outcome in patients with diffuse large B-cell lymphoma 
treated with rituximab plus cyclophosphamide, doxorubicin, vincristine and prednisone. J Clin Oncol. 2012;30(28): 3460-7.

https://doi.org/10.1200/JCO.2011.41.4342

PMid:22665537

15. Sathyanarayanan V, Oki Y, Issa AK, AminAhmed M, Noorani M, AFanale M, B.Hagemeister F, S.Neelapu S, J.Nastoupil L, Fowler N, Turturro F, Davis R, Rodriguez A, Wang M, FengMS L, H.Young K, J.McDonnell T, CPinnix C, Westin JR. High risk diffuse large B cell lymphoma: a comparison of aggressive subtypes treated with dose adjusted chemotherapy-the University of Texas MD Anderson Experience. American Society of Hematology. Washington, DC; 2016. https://doi.org/10.1182/blood.V128.22.106.106

16. Kawashima I, Inamoto Y, Maeshima AM, Nomoto J, Tajima K, Honda T, Shichijo T, Kawajiri A, Takemura T, Onishi A, Ito A, Tanaka T, Fuji S, Kurosawa S, Kim SW, Maruyama D, Tobinai K, Kobayashi Y, Fukuda T. Double-Expressor Lymphoma is associated with poor outcomes after allogeneic hematopoietic cell transplantation. Biol Blood Marrow Transplant. 2018;24:294-300.

https://doi.org/10.1016/j.bbmt.2017.10.013

PMid:29037890

17. Zhang Y, Wang H, Ren C, Yu H, Fang W, Zhang N, Gao S, Hou Q Correlation Between C-MYC, BCL-2, and BCL-6 protein expression and gene translocation as biomarkers in diagnosis and prognosis of diffuse large B-cell lymphoma. Front Pharmacol. 2019;9:1497.

https://doi.org/10.3389/fphar.2018.01497

PMid:30666200 PMCid:PMC6330311

18. Kluk MJ, Chapuy B, Sinha P, Roy A, Dal Cin P, Neuberg DS, Monti S, Pinkus GS, Shipp MA, Rodig SJ. Immunohistochemical detection of MYC-driven diffuse large B-cell lymphomas. PLoS ONE. 2012;7:e33813. https://doi.org/10.1371/journal.pone.0033813

PMid:22511926 PMCid:PMC3325231 